\title{
ECONOMIC CRISIS OF A MIDDLE INCOME COUNTRY AS AN AFTERMATH OF COVID-19 PANDEMIC
}

\author{
Mohammad Tahsin Islam ${ }^{1}$, Dr Irin Hossain², Dr Ashekur Rahman Mullick² \\ ${ }^{1}$ Gerico France, Paris, France \\ ${ }^{2}$ National Institute of Preventive and Social Medicine (NIPSOM), Dhaka, Bangladesh
}

DOI: 10.46609/IJSSER.2020.v05i07.020 URL: https://doi.org/10.46609/IJSSER.2020.v05i07.020

\begin{abstract}
The economic situation of Bangladesh as a middle income country due to Covid-19 however depends on the extent of the crisis. Its economic fate is closely tied to the fate of ready-made garments (RMG) and inward remittance. RMG sector accounts for around $80 \%$ of the country's total export earnings. A reduction in exports of as much as 84\% in April 2020 compared with that of the previous year. More than 1,000 factories have been closed and 2.19 million out of 4 million workers lost their jobs. Remittances from Bangladeshi migrant workers are expected to fall by $25 \%$ this 2020 . SME's are usually the worst hit at the times of economic disorder. Banks are trying to come to terms with the Ministry of Finance directive of $6 \%$ and $9 \%$ caps to interest rates on deposits and loans; vulnerable asset quality; moribund capital markets; and a struggling microfinance sector. The economy is now almost coming to a grinding halt with weakening effects on all sectors like educational systems, Banks, FDI, small business, tourism industries, dairy and vegetable producers etc. Daily wage earners are unable to buy food for their families. Hunger, malnutrition, and other problems that have always plagued Bangladesh are poised to intensify as a result of the lockdown. The current economic state may seriously undermine the livelihood of the underprivileged cohort of the population. Lack of access to basic healthcare, knowledge of hygiene and a social safety net have always been a challenge for this cohort.
\end{abstract}

Keywords: Economic Crisis, Middle Income Country, COVID-19 Pandemic.

\section{INTRODUCTION}

The whole globe is going under a devastating threat of economic depression amid impact of COVID-19 pandemic. Almost no country can deny the fact propelling to the economic ramification of this diseases suggesting a confirmed apropos plan to recuperate any unavoidable circumstance in forthcoming economic arena. A middle income country like Bangladesh with no 
International Journal of Social Science and Economic Research

ISSN: 2455-8834

Volume: 05, Issue: 07 "July 2020"

exception is also capitulated under a significant threat of economic disparity navigating a colossal crisis during and after this epidemic. Following the depressing mode of major economic indicators such as inverse trade growth, vigorous revenue deficit, mounting non-performing loan, falling private sector investment, volatility of market interest rate, capital market unrest and imminent horrid of global economic recession ${ }^{1}$.

The economic crisis triggered by COVID-19 is deepening over time in Bangladesh. If the deep recession and economic downturn is prolonged, then there is a high risk of social crisis too ${ }^{2}$. There is no doubt that during this economic crisis all the major drivers of Bangladesh's economy have been seriously affected which include the export sector, remittances, domestic industries and services, livestock and fisheries, and small and medium enterprises. This crisis also has a tremendous effect on the country's poor and vulnerable people ${ }^{3}$.

\section{METHODS AND MATERIALS}

This was a review study which attempts to reveal those possible impacts that are causing economic crisis for a middle income country like Bangladesh and how government along with all other stakeholders will respond to sustain socio-economic developments achieved during the recent fiscal years. This paper cannot produce any quantitative estimate of the future as it is mid stage of outbreak of coronavirus in Bangladesh. We collected the information from materials published so far by different media outlets, think tanks, research agencies, policy experts and newspapers. Besides this, the internet has been used as another source of information.

\section{INTERNATIONAL REMITTANCES AND BANGLADESH DURING COVID-19}

In an overview:

- Remittances from Bangladeshi migrant workers are expected to fall by $25 \%$ this year.

- The coronavirus pandemic highlights the need for better cooperation over migration.

- Bangladesh has offered incentives to encourage expatriate workers to send their money through legal channels.

- Public bodies and remittance services providers must improve access to digital solutions.

The economic importance of the more than 10 million migrants from Bangladesh who sent close to $\$ 18$ billion in 2019 cannot be overstated. International remittances normally represent around 7\% of Bangladesh's GDP. But the COVID-19 pandemic is having an acute effect on Bangladeshi migrants abroad, who are largely concentrated in countries with strict lockdown measures. Considering the large volume of Bangladeshi migrants in the Middle East, secondary economic impacts through depressed demand and falling oil prices will also likely add strain to the flow of remittances. 
International Journal of Social Science and Economic Research

ISSN: $2455-8834$

Volume: 05, Issue: 07 "July 2020"

World Bank estimates have projected that total remittances by migrant workers from Bangladesh will fall to $\$ 14$ billion for 2020 - around a $25 \%$ decrease from the previous year. Figures released by Bangladesh Bank show that year-on-year remittances for the month fell by $25 \%$, indicating that the World Bank's projection is, unfortunately, likely to hold true. The drop in these payments, which have traditionally averaged between $\$ 300$ and $\$ 600$ a month, will represent a significant loss to millions of household incomes in Bangladesh ${ }^{4}$.

Bangladesh's manufacturing sector has suffered a huge blow, especially the ready-made garments sector, which accounts for around $80 \%$ of the country's total export earnings. At least 4 million workers depend on the textile industry for their livelihood. After the pandemic hit Europe and the US, the industry experienced a reduction in exports of as much as 84\% in April 2020 compared with that of the previous year. More than 1,000 factories have been closed and 2.19 million workers lost their jobs, according to the NGO study. According to the Export Promotion Bureau of Bangladesh (EPB), in March this year the export earnings were just 44.14 billion taka ( $€ 460.5$ million, $\$ 520$ million), down from 256.66 billion taka ( $€ 2.68$ billion, $\$ 3.03$ billion) in the same month of last year'.

Remittances from Bangladeshi workers accounted for $\$ 15.5$ billion to the national economy in 2018. Now host countries in Europe and the Middle-East are themselves facing economic slowdown causing large-scale layoffs of migrant worker. Most of them are now returning home to Bangladesh and on return heading towards their country homes exacerbating the health crisis ${ }^{2}$.

Moreover, oil prices have fallen precipitously, which is expected to aggravate demand for migrant workers. Oil prices are often an effective leading indicator of inward remittances (Figure 1). History shows that falling oil prices have a lagged effect on remittances into Bangladesh. At present, prices are falling because of reduced demand from sectors such as aviation and transportation sectors, as well as the Russia-Saudi Arabia price war. Overall, the drop in export revenues, RMG worker layoffs, and reduced flow of remittances will impact demand in the urban and rural consumer economy of Bangladesh. 


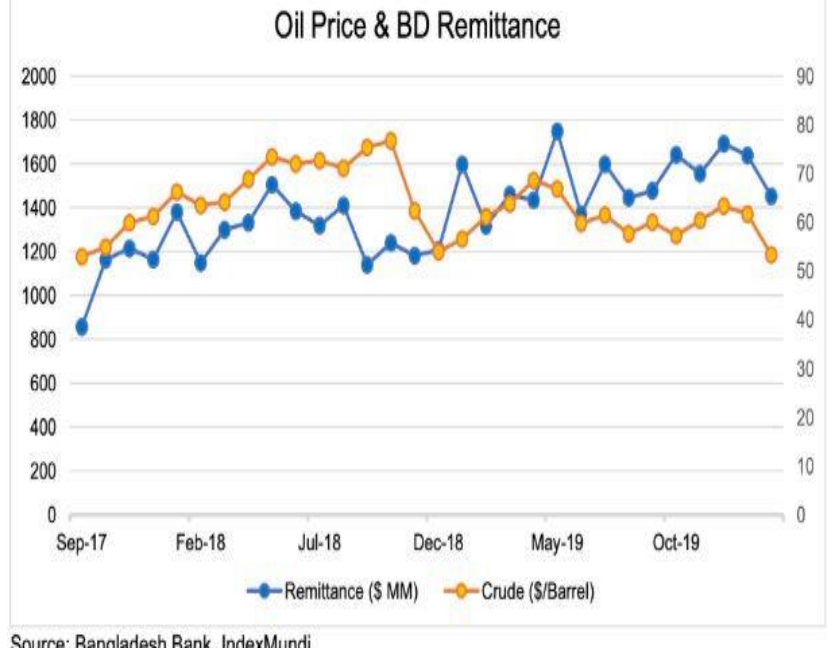

Fig. 1: Relationship between crude oil price and BD remittance

\section{ECONOMIC CHALLENGES DURING COVID-19 AND BANGLADESH}

According to the Bangladesh Bureau of Statistics (BBS), 20.5 per cent of the population live below the poverty line that is about 34 million people and 85.1 per cent of work force are employed in the informal sector, that is about more than 50 million people. Most of these workers in the informal sector are also underemployed. Now the pandemic has further worsened their employment prospects. It is now estimated that the pandemic has rendered 80 per cent workers unemployed in the informal sector. Only 6 million people are employed in the formal sector, largely in manufacturing ${ }^{2}$.

Nearly 10 million Bangladeshis are working in foreign countries, mostly in the Gulf countries. Now the depressed oil prices affecting the Gulf states and lockdowns imposed in Europe since April are already causing serious economic slowdown in these countries having a negative impact on expatriate Bangladeshi workers abroad ${ }^{2}$.

Economic slowdown in Europe and North America is of particular concern for Bangladesh as these are the principal markets for Bangladesh's principal export product -- readymade garments (RMG). These two regions are also expected to continue to slow down at least for next six months or more and that has implications for 4 million workers in the RMG industry in Bangladesh $^{2,5}$.

\section{IMPACT ON POVERTY REDUCTION}

The global health crisis caused by COVID-19 has hit Bangladesh's economy hard and jeopardized the country's impressive achievements in poverty reduction. According to the South 
International Journal of Social Science and Economic Research

ISSN: $2455-8834$

Volume: 05, Issue: 07 "July 2020"

Asian Network on Economic Modelling (SANEM), Bangladesh's poverty rate may double to $40.9 \%$ from that prior to the onset of the pandemic. Experts underline that if the current economic distress is not handled properly, the rise in inequality between the rich and the poor might create long term socio-economic damage within Bangladeshi society ${ }^{3,5}$.

\section{FOOD SECURITY DURING COVID-19}

As the government has announced a large stimulus package, the effectiveness of this stimulus package, however, depends on the use of appropriate financing options, proper management so that genuinely affected sectors receive the support, and establishment of a proper monitoring mechanism to ensure transparency and accountability. To ensure food security for the poor and vulnerable, it is important to distribute essential food items quickly at the local level based on the government's list of poor people under the social security programme. New lists need to be drawn up quickly to include the excluded poor and vulnerable population. Local administrations, peoples' representatives, private sector, volunteers and NGOs need to work together at the local level to prepare and update lists, distribute food, and avoid irregularities in the process. Capable private sector individuals and private sector organisations (such as BGMEA, FBCCI, MCCI, DCCI) need to come forward to ensure food security for their workers and staff $^{3}$.Developing countries like Bangladesh, particularly small island development states (SIDS), dependent on tourism have already experienced a precipitous collapse in their revenues given that international travel has come to a halt. These losses make it more difficult to pay for the imported food required for survival in these countries ${ }^{6}$.

\section{MINIMISE ECONOMIC IMPACT BY EASING LOCKDOWN}

In today's COVID-19 stricken world, a large part of the debates on whether and how the countries should ease the lockdown is shaped by the logic of saving the economy. The Bangladesh government, for example, has started easing the lockdown restrictions to minimise the economic impact.

In the 1920s, American Biologist, Raymond Pearl put some Drosophila (fruit flies) in a closed bottle with some foods in his laboratory. He then plotted the number of living flies overtime on a graph and showed how their population growth saturated at one point. Soon he turned his experiment with the flies to make a universal claim on "how things grow" for all living organisms, including humans. He argued that, like the closed bottle, a national economy could only host a maximum size of the population for a more extended period. This argument was widely used by many governments as well as local and international organisations to legitimise the exploitation of racialized, female, colonised, working, and disabled bodies in the name of managing population and saving the economic futures. For example, instead of encouraging 
redistribution and equitable allocation of resources, many countries in the Global South were directed to "control" their population through forced sterilisations and unsafe experimental birth control methods in the 1980s and 1990s. The logic of economic development was at the heart of those top-down population control measures, which affected the bodies, health, and well-being of many women from working-class, racialized, and marginalised backgrounds ${ }^{7}$.

\section{IMPACT ON SMALL BUSINESSES AND START-UPS}

Small businesses and startups are usually the worst hit at the times of economic disorder. Raising funds is hard as it is, for small businesses and startups. When it comes to SME's, in an environment of $6 \%$ and $9 \%$, access to finance will become more difficult as banks will be reluctant to make SME loans at $9 \%$, since SME operations are more expensive for banks. For Banks were trying to come to terms with the Ministry of Finance directive of $6 \%$ and $9 \%$ caps to interest rates on deposits and loans; vulnerable asset quality; moribund capital markets; and a struggling microfinance sector as access to donor funds and bank financing become morecompetitive. Private sector credit growth was already declining (Figure 2). Despite having huge amounts of excess liquidity, banks were reluctant to lend amid the pressure of implementing single digit lending rate, which came into effect from April 1, 2020.

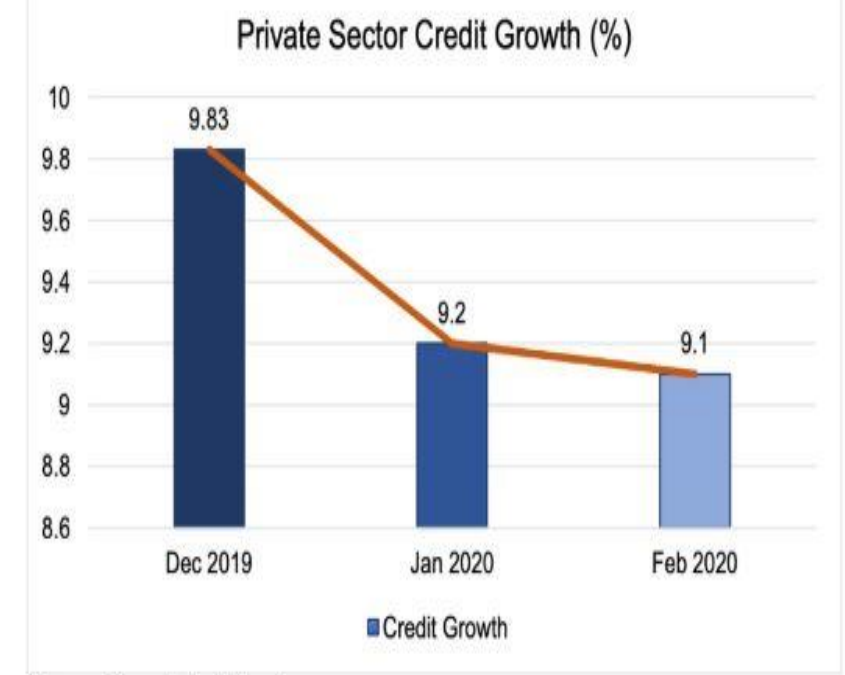

Source: Bangladesh Bank

Fig. 2: Growth rate of private sector credit

However, the Bangladesh government has come out strongly and in a timely manner announcing a multi sector stimulus package that will shore up RMG businesses, provide direct incentives to workers, buttress the banking system, ensure liquidity in the economy, enable reprieve to 


\section{International Journal of Social Science and Economic Research}

ISSN: $2455-8834$

Volume: 05, Issue: 07 "July 2020"

exporters and importers, and provide support to other impacted sectors such as tourism, aviation, and hospitality ${ }^{8}$.

\section{IMPACT ON HEALTH SECTOR}

The Covid-19 crisis perceived to be concerned with health crisis; however, prevention measures against the infection lead to an economic crisis. The discussion on health and economic crises should thus follow in tandem. The pandemic unfolds nakedly the weaknesses of our public health sector. However, it is the minimum basics that our public health sector lacks. Public hospitals do not have the minimum number of ICU beds, oxygen supply system, diagnostics lab, necessary manpower-not only doctors, but also other support staffs, technologists etc., to name a few. It reveals that a coterie was behind this situation to serve their own interest, that is, to conduct their private health-related businesses. Worse yet, private sector is now not willing to support the government's effort to contain the crisis. As a result, many COVID-19 patients are dying because they are not getting due treatment in the hospitals. Private hospitals and clinics are not even providing treatment to non-COVID-19 patients.

The health sector warranted a bigger budgetary allocation this year to combat COVID-19 pandemic with particular emphasis on the improvement of public health support system. A 23\% increase is seen in the health sector budget (about $0.6 \%$ of GDP, which is still lower than the South Asia average compared to last year with additional block allocation of 10,000 crore taka to meet incidental costs. This higher allocation is a welcome move; however, considering the haphazard situation in the public health sector, this allocation does not appear to be adequate. This typical allocation reveals the fact that the current health and finance administration could not realize or envision the need for a bigger allocation within their capacity ${ }^{9}$.

\section{CONCLUSION}

Damages to the Bangladesh economy will depend largely on extent and pervasiveness of Covid19, as well as effectiveness of government measures to tackle the disaster. The post-COVID-19 world will not be the similar again. The new normal may come up with changed lifestyle, buying pattern and way of doing business through new interfaces. The post-pandemic solutions of unique difficulties that we are facing through this pandemic may lay the foundation for many business ideas and can shape the impending of our e-commerce industry in the coming years.

\section{REFERENCES}

1. Lalon, Raad Mozib, COVID-19 vs Bangladesh: Is it Possible to Recover the Impending Economic Distress Amid this Pandemic? (April 18, 2020). Available at SSRN: https://ssrn.com/abstract=3579697 or http://dx.doi.org/10.2139/ssrn.3579697 
International Journal of Social Science and Economic Research

ISSN: $2455-8834$

Volume: 05, Issue: 07 "July 2020"

2. Covid-19: Economic challenges facing Bangladesh: The Financial Express, access on: 01.07.2020 Available at: https://thefinancialexpress.com.bd/views/covid-19-economicchallenges-facing-bangladesh-

1592064588?fbclid=IwAR2sCtt0tjUhN_wCrQAC679Ap3jTKQiIVXsNFK0UfJ10Bx2Ou WMedsv6-jA

3. Covid-19 induced economic crisis in Bangladesh: What needs to be done: TBNews, access on: 02.07.2020 Available at: https://tbsnews.net/analysis/covid-19-induced-economiccrisis-bangladesh-what-needs-be-done-

80197?amp\&fbclid=IwAR1i4TctjXvxYswz8edio5B-GEmsJFVUyWEFsYIjHQ5TivHiAKJN5Xkouw

4. Bangladesh faces a crisis in remittances amid COVID-19: World Economic Forum, access on: 09.07.2020 Available at: https://www.weforum.org/agenda/2020/06/bangladesh-facesa-remittances-crisis-amid-covid-

19/?fbclid=IwAR142FT2c0TPD2J3QKQk0nMpa4HQD2k9wZt3ftmKVp0ULSY9YrxeBk $\underline{\text { a } \_ \text {YZk }}$

5. Coronavirus: Economy down, poverty up in Bangladesh, access on: 05.07.2020 Available at: $\quad$ https://amp.dw.com/en/coronavirus-economy-down-poverty-up-in-bangladesh/a53759686?fbclid=IwAR2yoVlMzYSKWscbvpUtAQhw_Xh5DdR6TgY8x6ZvnJQpLYno X9nq9mvEL44

6. Rahman S, Hossain I, Mullick A R, Khan M H, Food Security and the Coronavirus Disease 2019 (COVID-19): A Systemic Review, Journal of Medical Science and Clinical Research, DOI: https://dx.doi.org/10.18535/jmscr/v8i5.34

7. COVID-19 and the economization of life in Bangladesh, The Daily star, access on: 07.07.2020 Available at: https://www.thedailystar.net/opinion/news/covid-19-and-theeconomisation-life-bangladesh-1901326?amp

8. Coronavirus and the Bangladesh economy: Navigating the global COVID-19 shutdown; Available at https://blogs.lse.ac.uk/southasia/2020/04/03

9. A compassionate management of Covid-19 crisis is the key to economic recovery Available at https://thefinancialexpress.com.bd/views/opinions/a-compassionatemanagement-of-covid-19-crisis-is-the-key-to-economic-recovery-1592752318 


\begin{abstract}
ABBREVIATIONS
COVID-19: Corona Virus Disease 19.

RMG: Ready-made garments.

SME: Small and medium-sized enterprises.

FDI: Foreign direct investment.

GDP: Gross domestic product.

EPB: Export promotion bureau of Bangladesh.

BBS: Bangladesh Bureau of Statistics.

SANEM: South Asian Network on Economic Modelling.

BGMEA: Bangladesh Garment Manufacturers and Exporters Association.

FBCCI: Federation of Bangladesh Chambers of Commerce \& Industries.

MCCI: Metropolitan Chamber of Commerce and Industry, Dhaka.

DCCI: Dhaka Chamber of Commerce Industry.
\end{abstract}

\title{
AUTHOR'S INFORMATION:
}

Principal Author:

\section{Mohammad Tahsin Islam}

Resident Engineer (Civil), Agro-industrial Engineering

Gerico France, Paris, France. 
International Journal of Social Science and Economic Research

ISSN: 2455-8834

Volume: 05, Issue: 07 "July 2020"

\section{Corresponding Author:}

\section{Dr Irin Hossain}

Assistant Professor,

Department of Occupational and Environmental Health.

National Institute of Preventive and Social Medicine (NIPSOM), Dhaka, Bangladesh.

\section{Dr Ashekur Rahman Mullick}

Data Enumerator

National Institute of Preventive and Social Medicine (NIPSOM), Dhaka, Bangladesh. 